\title{
Inclusion of the Children with Disabilities among School in Algeria
}

\author{
Dr. Saad Eddine Boutebal \\ Social Sciences Department \\ Khemis Miliana University \\ Algeria \\ Dr. Samia Yahi \\ Social Sciences Faculty \\ Algiers University 2 \\ Algeria
}

\begin{abstract}
Recently, many countries in the world have focused on promoting education of disabled children to qualify them in order to interact with the society they belong to. It is worth stating that the education of disabled children who are enrolled in regular schools has shifted from integration to inclusion. The idea of inclusion came out as a result of a limited capacity and efficiency faced by integrating education. The developed countries have achieved considerable steps in this domain, regardless the problems they still face. But, what about developing countries? Especially, if we bear in mind that a huge number of disabled children are not yet enrolled in any school. With reference to these important facts, we have decided to assign our paper on Algerian experience in this domain. The point is that Algeria has made education of normal children and disabled as its first priority. So, what are the policies and strategies that have been adopted in Algeria to support education of disabled children? And this is what we are going to present by emphasizing on the Algerian experience.
\end{abstract}

Keywords: Disability, Childhood, Inclusion, Integration, Education.

\section{Introduction}

According to the statistics of the National Bureau of Statistics (2010) published by the Ministry of National Solidarity and Family, about 130,000 children with disabilities are under the age of five (Aguoun Asia 2012, p. 187).

Disability refers to a permanently fixed state resulting from illnesses, accidents, or congenital defects. We can distinguish between two types of disability: physical and mental. Mental retardation is more important. It leads to social marginalization and to learning difficulties, that may be significant or minor (Lamine, 2007, p. 336) As defined by the International Classification of Disability (CIF) and Health, focusing on the deficiency experienced by the person on the one hand and the role of the environment on the other one, which may appear as a facilitator or obstacle. (43Rapport national sur les personnes handicapées, 2014, p)

The environment of the disabled person may be general, and the disabled child in particular is troubled with obstacles, whether in the social, geographical or educational environment. The latter plays an important role in shaping the personality. Moreover, it participates in the development of the handicapped child, and thus raising his self-esteem and rehabilitation to interact with his society. This also concerns their collective citizenship and active participation.

The study of the educational environment has led us to talk about the course of education for the handicapped child. Thus, the process of studying for handicapped children in most countries (America, France, Britain, etc.) has gone through three phases. In the early seventies, the stage of segregation, where children with special needs are in specialized institutions away from ordinary children. This type of schooling allows for an appropriate response to these children through specialized specialists and practices.

From the mid-1970s to the 1990s, a new phase of integration education at the standard school level has been introduced, thanks to a series of reports submitted by a number of countries and international declarations (United Nations 1993, UNESCO, 1994). 
This concerns children with disabilities who affirm the right of persons with disabilities to participate in social life the competent institutions remained open in some countries to receive children who are unable to attend normal schools because of their disability (Thomazet, 2008, p127)

Gossot (2002) points out that integrated education treats the disabled child in the normal school as a personal dimension.It is primarily based on the child's effort to adapt to the school and its employment standards, while providing personal assistance that allows them to pursue education as it is.(Galasso-Chaudet \& Chaudet, 2015, p133)

This type of education does not provide the right conditions for the disabled child to learn.But, the latter must do his best to follow up and assimilate the lessons and to integrate into the group (Manuel de formation des enseignants en éducation inclusive, 2012, p14)

There has been a significant changes in inclusive education, its objectives, implications and effects during the 1990s, mainly because of recognizing that existing integration models only close specialized schools, add handicapped students to regular schoolchildren, and follow normal curricula that do not respond to the learners' expectations and needs, to be of a great benefit (International Conference on Education, 2008, p. 9). As a result of all these considerations, educational policies in many countries of the world, especially western ones, have turned to a different form of education called education inclusive. However, the call for inclusive education, or education for all was achieved only in 1994 with the Salamanca Conference. It stated that regular schools provide high quality education to all pupils, including persons with disabilities, without discrimination. Moreover, UNESCO Guidelines for Integration (2005) states that the essence of education for all is the human right to education (OHCHR Annual Report, 2013, p. 5)

The use of the word inclusion rather than integration was specifically chosen after the presentation of the international lecture "Education for All" in 1990 in Jomtien Thailand. It reflected a better will to put an end to the separation and discrimination that prevailed. 2010, p143-144)

Inclusive education for children with a disability status is intended to teach all children without exception in the departments or educational institutions of the child's neighbourhood. These are preferred places for diversity and other learning (Stanback, Villa and Thousand, 2005) Tant et Waitelain, 2014, p38). According to Armstrong (1998), integrative education is a radical situation that requires that the sections themselves can be transformed into school groups, where all teachers are received under the rule of equal rights.

(Plaisance et Belmont, 2007, p160)

The integration of handicapped children is a major challenge that many countries are trying to raise. However, many of them, such as France, face many problems, including the large number of disabled people, lack of resources, etc., and each country has its own educational strategy in this field. As far as the problem of integrated education in our country is concerned, what have we prepared for that, and what strategy we have taken? We will present this through the Algerian experience in the field of education for disabled children.

The term 'intégration' was used by Rouhi Marouhe Abdat (2010) to express the merger. Rekab Anisa (2013) used the term intégration to indicate the integration of the integration, as preferred Emad Farouk Mohammed Saleh (2011) word merger to express the INCLUSION. The translation that we will use in this paper is the "integration" of the word intégratif and the "integration" of the word inclusif.

\section{Basic concepts}

\section{Integrated education (L'éducation intégrative):}

Sue Stubbs (2002) has seen it as a type of education for children with disabilities in a mainstream or normal environment. The disabled child is accepted at the regular school level. But, he receives lessons by a professor in a separate department. In inclusive education, the educational system does not adapt to the needs of the disabled child, but to what is happening as it is the other way around, since it is the child who has to adapt to this educational system.

The disabled child is received at school without any discrimination in the teaching methods and the course of ordinary children, and the success of such integration can only be achieved if the child takes special care. In fact, the integrative education seeks to change or re-educate the child in order to integrate him in the educational system and society. 
In this type of education, it is the disabled learner who must adapt to the educational system with a variety of skills, and not the opposite (Manuel de formation des enseignants en éducationinclusive, 2012, p12-13)

We conclude from the foregoing that integrated education is based on the reception of disabled children, regardless of their disability, in an ordinary school environment next to their peers from ordinary children.

The learner (disabled) in this model of education is subjected to a rigorous assessment process, or will be combined with ordinary children in some articles.

\section{2- Education inclusive:}

Integrative education is a process that takes into account the different needs of each child. It allows for participation in learning, cultural life, and group life. It also aims to reduce marginalization within, and outside the school. This type of education requires changes and transformations in the content of school programs; it also depends on the belief that the normal educational system is primarily responsible for the education of all children (Wormanaes, 2005, p82).)

Plaisance (2007) adds that the integrative school accepts all differences, and assumes that the educational system adapts to the specificities of the child (Voyazopoulos, 2016, p14). Integrated education involves a type of education that dissolves individual differences, all disabled children receive whatever their disability is, with their peers from ordinary children in the same classes, adapting the educational environment and making it more appropriate in terms of programs, buildings, school equipment. .etc. Having identified the basic terms that we have adopted in this article, we shall now begin to present the Algerian experience.

\section{The potential of integrating children with disabilities into the school:}

In fact, the Ministry of National Solidarity is working to encourage the inclusion of children with disabilities in the normal school environment of national education. This is done by circulating the process of opening specialized sections at the level of all states in coordination with the national education sector (Programs for protection and promotion Persons with Disabilities), July 2016).

The process of caring for children with sensory disabilities (the hearing weakened and the blind) started in the integration sections in the normal school environment during the 1990s, prior to the issuance of the joint ministerial decision of 10 December 1998, which included the opening of special sections for the hearing weakened and the blind in the educational institutions of the sector of National Education. (Document Education et enseignement spécialisés pour enfants handicaps en milieu ordinaire, ministère de solidarité nationale, de la famille, et de la condition de la femme, mai 2015)

This arrangement, which previously covered only children with sensory disabilities, was extended to include children with a minor mental disability. Under a joint ministerial decree dated March 2014 between the Ministry of National Solidarity and the Ministry of National Education, it defines how to open special sections for disabled children in the educational institutions of the education sector (Data document on programs for persons with disabilities and their promotion, Ministry of National Solidarity, 2016). Special classes for the disabled are provided by:

Eight (08) to twelve (12) children at most, for children with hearing or visual weakening. Six (06) to 10 (10) children with a minor mental disability. (Document Education et enseignement spécialisés pour enfants handicapés en milieu ordinaire, ministère de solidarité nationale, de la famille, et de la condition de la femme, mai 2015)

The overall inclusion of disabled children is also supported in sections for ordinary children, especially at the middle and secondary levels. The number of special departments open for this school year 2015-2016 has reached 414 in 41 provinces and 282 departments during the 2014-2015 academic year, including 250 special sections for children with minor mental disabilities. The level of these special sections is 3246 disabled children among them (1326 girls). (Programs for the Protection and Promotion of Persons with Disabilities, Directorate General for the Protection and Promotion of Persons with Disabilities, July 2016)

They are distributed according to the type of disability as follows:

- A mild mental disability: 2120 children, including 811 females.

- Hearing impairment: 1073 students, including 490 females.

- Visual disability: 53 students, including 28 females. 
Table (01): shows the evolution of the number of open private departments in Algeria

\begin{tabular}{|c|c|}
\hline Year & $\begin{array}{c}\text { Number of open year } \\
\text { sections }\end{array}$ \\
\hline 2000 & 23 \\
\hline 2005 & 31 \\
\hline 2010 & 54 \\
\hline 2014 & 208 \\
\hline 2015 & 282 \\
\hline 2016 & 414 \\
\hline
\end{tabular}

(Data document on programs for persons with disabilities and their promotion, Ministry of National Solidarity, 2016)

From the data in the above table, we can deduce that there is a significant increase in the number of open special classes, especially since 2014 when the doors of special classes for children with intellectual disabilities were opened. This indicates the seriousness of interest in this category and work on promoting it in the best conditions. Table (02): shows the evolution of the number of integrated disabled children

\begin{tabular}{|c|c|}
\hline Year & $\begin{array}{c}\text { Number of open year } \\
\text { sections }\end{array}$ \\
\hline 2000 & 158 \\
\hline 2005 & 278 \\
\hline 2010 & 557 \\
\hline 2014 & 1745 \\
\hline 2015 & 2482 \\
\hline 2016 & 3246 \\
\hline
\end{tabular}

(Data document on programs for persons with disabilities and their promotion, Ministry of National Solidarity, 2016) According to the data of Table (02), there is a remarkable development in the number of handicapped children who are integrated into the special classes, especially since 2014. The Ministry of National Solidarity and the Ministry of National Solidarity, dated 13 March 2014, define the modalities of opening special divisions for children with disabilities within the public education institutions of the national education sector.

\section{Primary and Middle school end Exams:}

Table (03): Success rate, Number of successful, Number of candidates and Nature of disability

\begin{tabular}{|c|c|c|c|}
\hline Nature of disability & Number of successful & Number of candidates & Success rate \\
\hline Hearing impairment & 327 & 371 & $88.14 \%$ \\
\hline Visual impairment & 91 & 93 & 97.84 \\
\hline Motor disability & 3 & 4 & $75 \%$ \\
\hline Shortness of breath & 6 & 11 & $54.54 \%$ \\
\hline Integrated sections & 119 & 130 & $91.53 \%$ \\
\hline Total & 546 & 609 & $89.65 \%$ \\
\hline
\end{tabular}

According to findings in Table (03), the success rate of learners with disabilities is varied and is considered as the best in terms of results achievement. Then, this reflects the outstanding work embodied with those children. This is an incentive for achieving the best teaching results that meet the expectations of children with different disabilities. 


\section{Certificate of Middle School Education (fourth year average)}

Table (04): Success rate Number of successful Number of candidates Nature of disability

\begin{tabular}{|l|c|c|c|}
\hline \multicolumn{1}{|c|}{ Nature of disability } & $\begin{array}{r}\text { Number of } \\
\text { successful }\end{array}$ & $\begin{array}{r}\text { of } \\
\text { candidates }\end{array}$ & Success rate \\
\hline Hearing impairment & 46 & 145 & $31.72 \%$ \\
\hline Visual impairment & 78 & 91 & $85.71 \%$ \\
\hline Motor disability & 4 & 5 & $80 \%$ \\
\hline Shortness of breath & 1 & 5 & $20 \%$ \\
\hline Integrated sections & 17 & 66 & $25.75 \%$ \\
\hline \multicolumn{1}{|r|}{ Total } & 146 & 312 & $46.79 \%$ \\
\hline
\end{tabular}

According to the data in Table (04), the achieved results with visual and motor disabled people were distinct. Nevertheless, we notice a weakness in people with other disabilities. This is due to the difficulty of the teaching process on the one hand. On the other hand, it is because of its requirement for the specialists and professionals. This pushes the concerned institutions to work on developing their human qualifications adhering the latest advancements and so for the requirements of cases to increase efficiency and better results achievements.

\section{Conclusion}

We can say that the field of education for children with special needs in Algeria is particularly well considered both in terms of legislation, and pedagogy. This is evident from the developments in this field, such as; the increasing number of integrated children with disabilities. But, more efforts are needed by the establishment of an effective policy and strategy of efficient education, with the participation of the ministries concerned. In addition to the need to make changes and changes to our educational system, with more appropriate programs and a suitable educational environment for these children, in order to facilitate the process of rehabilitation and their interaction in the community.

\section{Bibliography}

Annual report of the United Nations High Commissioner for Human Rights, thematic study on the right of persons with disabilities to education, twenty-fifth session, Human Rights Council, General Assembly, United Nations.

Passengers, Anissa (2013). School integration for the hearing impaired: Algerian experience. Academy for Social and Human Studies c / Department of Social Sciences No. 10, Joan, pp. 45-51.

Problems in the Integration of People with Visual Disabilities in the United Arab Emirates, Series of Disability Studies in the UAE, June (Issue 1)

Akoun, Asia (2012). Occupational Stress and its Relation to the Response of Concern among Special Education Teachers, Unpublished Master Thesis in Clinical Psychology, University of Setif.

United Nations Educational, Scientific and Cultural Organization, Inclusive Education: The Way to the Future, International Conference on Education, Forty-eighth Session, November 2008

Bouabdallah, M (2013). Les obstacles et facilitateurs de l'éducation des enfants en situation de handicap en milieu ordinaire. El-Tawassol : Economie, Administration et Droit, N³5 - Septembre 2013.université Ferhat Abbes. Sétif 2.

Fall, L ; M-L, Diouf; M- H, Thiam; O-S, Momar.Gueye.(2007). Handicapet école auSénégal.EDK, Groupe EDP Sciences | «Perspectives Psy ».Vol. 46 | pp 336 à 340.

Galasso-Chaudet, N; V , Chaudet. (2015). L'inclusion scolaire en question(s). Impact sur les pratiques enseignantes.ERES Vie sociale $n^{\circ} 11 \mid$ pages 127 à 145.

Garel, J-P. (2010).De l'intégration scolaire à l'éducation inclusive:D'une normalisation à l'autre. Journal des Anthropologues, pp143-165.

Manuel de formation des enseignants en éducation inclusive. le Ministère de l'Education Nationale du Burkina Faso et de l'Alphabétisation Avec le soutien de Handicap International. Juillet 2012. 
Plaisance, E; Belmont, B.(2007). Intégration ou inclusion? .Éléments pour contribuer au débat. La nouvelle revue de l'adaptation et de la scolarisation - no $37 \cdot 1$ er trimestre.

Rapport national sur les enfants non scolarisés «Tous à l'école», Algérie, Unicef .Octobre 2014.

Tant, M ; E ,Watelain (2014).Attitudes des enseignants d'éducation physique envers l'inclusion d'un élève en situation de handicap. Une revue systématique de la littérature (1975-2015).De Boeck Supérieur/N 106.pp 37-53.

Thomazet, S .(2008). L'intégration a des limites, pas l'école inclusive. Revue des Sciences de l'Education, Volume 34, no 1, 2008123 - 139

Voyazopoulos, R(2016).Handicap mental, psychique ou cognitif dans l'enfance: De l'évaluation psychologique à l'inclusion scolaire en 2015.Champ Social/ « Pratiques en santé mentale »1-62é année. PP11à 25.

Wormnaes, S traduction M-F,Crouzier.(2005).Vers l'inclusion des enfants en situation de handicap.Eres/ « Reliance »/n 16/p75-83.

Documentation

Programs for the Protection and Promotion of Persons with Disabilities, Directorate General for the Protection and Promotion of Persons with Disabilities, July 2016.

Data document on programs for persons with disabilities and their promotion, Ministry of National Solidarity, Family and Women's Issues, 2016.

Program of Protection and Promotion of Persons with Disabilities, Directorate General for the Protection and Promotion of Persons with Disabilities, Ministry of National Solidarity, Family and Women's Issues, July 2016.(Protection and Promotion of Persons with Disabilities Act, Legislative and Regulatory Texts, Ministry of National Solidarity, Family and Women's Issues, 2014.

Communication No. 002 / 2014. Practical procedures for opening sections for children with disabilities, directed by the Ministry of Solidarity and National Education.

Communication No. 328/13 March 2006: Joint ministerial publication on educational follow-up and school examinations. The National Employment and Solidarity Ministries and the Ministry of National Education

Document Education et enseignement spécialisés pour enfants handicapés en milieu ordinaire, ministère de solidarité nationale, de la famille, et de la condition de la femme, mai 2015.

-Document Protection et promotion des personnes handicapées,2015, ministère de solidarité nationale, de la famille, et de la condition de la femme .

\section{Internet}

Vers l'inclusion des enfants en situation de handicap dans le système éducatif ordinaire »: retour d'expérience. www.hiproweb.org/fileadmin/cdroms/Inclusive_Education2014/RetourDExperienceAlgerie2012.pd,date et heure de consult,26/02/2016 à 17h 04min)www.un.org/ar/events/disabilitiesday/background.shtml 